\title{
Utilization process research of the soap industry acid waste water with high carbonate phosphorite of central Kyzylkum
}

\author{
Sanzharbek Shamuratov ${ }^{1}$, Umid Baltaev ${ }^{2}$, Umarbek Alimov ${ }^{3 *}$, Namazov Shafoat ${ }^{3}$, \\ Sherzod Kurambaev ${ }^{1}$, and Bazar Ibadullaev ${ }^{1}$ \\ ${ }^{1}$ Urgench State University, Urgench, Uzbekistan \\ ${ }^{2}$ JSC "Urganch yog'-moy", Urgench, Uzbeksitan \\ ${ }^{3}$ Institute of General and Inorganic Chemistry of the Academy of Sciences of the Republic of \\ Uzbekistan, Tashkent, Uzbekistan
}

\begin{abstract}
In the study, the process neutralization acid waster water from soapstock processing by high calcareous phosphorite of Central Kyzylkum at temperature $60^{\circ} \mathrm{C}$ by drainless technology was investigated. As a result, digested forms of $\mathrm{P}_{2} \mathrm{O}_{5}$ by citric acid and Trilon $\mathrm{B}$ in final products were ranged 30.28-50.43 and 25.58-39.93\%, respectively. Those types of products can be used under autumn chill.
\end{abstract}

\section{Introduction}

Soap making technology is of particular importance in the oil and fat industry. Indeed, at the last stage of alkaline refining of black oil, pasty oily sediment is formed - soap stock. Soap stock is the main raw material in the production of crude fatty acids (CFA), which is obtained on their basis of detergents, especially laundry soap, pharmaceuticals, cosmetics, lubricants, glycerin, etc. But the technology of processing soap stock, especially from cotton, is very complicated. The fact is that cotton soap stock contains saponifiable (neutral fat) and unsaponifiable (waxes, proteins, and dyes) substances that require special attention in technology since all of these substances make up a complex colloidal system of soap stock.

In this regard, there are two schemes for processing soap stock to obtain fatty acids. These are glutinous and sound modes [1]. They differ in the initial stage of processing, wherein the glue method, the soap stock is first subjected to saponification, and in the case of the sound method, the process includes, after saponification, a salting-out procedure $(\mathrm{NaCl})$, followed by settling and the release of soapy liquor. In both methods, after the initial treatment, the saponified raw material undergoes sulfuric acid decomposition, i.e., deoxidation followed by distillation of CFA and cooking soap with the addition of ingredients for the intended purpose. Figure 1 shows a scheme for processing cotton coast by the glue method (modified from the scheme [1]). It should be noted that this method, in contrast to the sound method, the entire mass after saponification without sediment is

* Corresponding author: umaralihonalimov@mail.ru 
transferred for decomposition. Hence it can be seen that the process as a whole is carried out in the complex alkaline-acid treatment of soap stock.

Soap stock with a $30-40 \%$ fat content from the refining shop through the supply tank 1 flows by gravity into the receiving tank 20 , from where it is pumped into the soap-making still 3. Here the soap stock is saponified with a $40-42 \%$ solution of alkali, which enters the vessel (still) 3 from tanks 2. Resaponification is carried out for 4-5 hours with thorough mixing of the contents of the still with steam to obtain soap glue with an excess content of free alkali of $0.2-0.3 \%$. The thus obtained saponified soap stock is fed from the still 3 using the pump 18 into the intermediate tank 16. Further, the saponified soap stock is pumped by the pump 17 into the reactor - boilers 6 for decomposition with sulfuric acid, which comes from the measuring tank 4. It is appropriate to mention here that the process of sulfuric acid decomposition is accompanied by high heat generation and requires a special technological procedure. In this regard, the process should be described in detail.

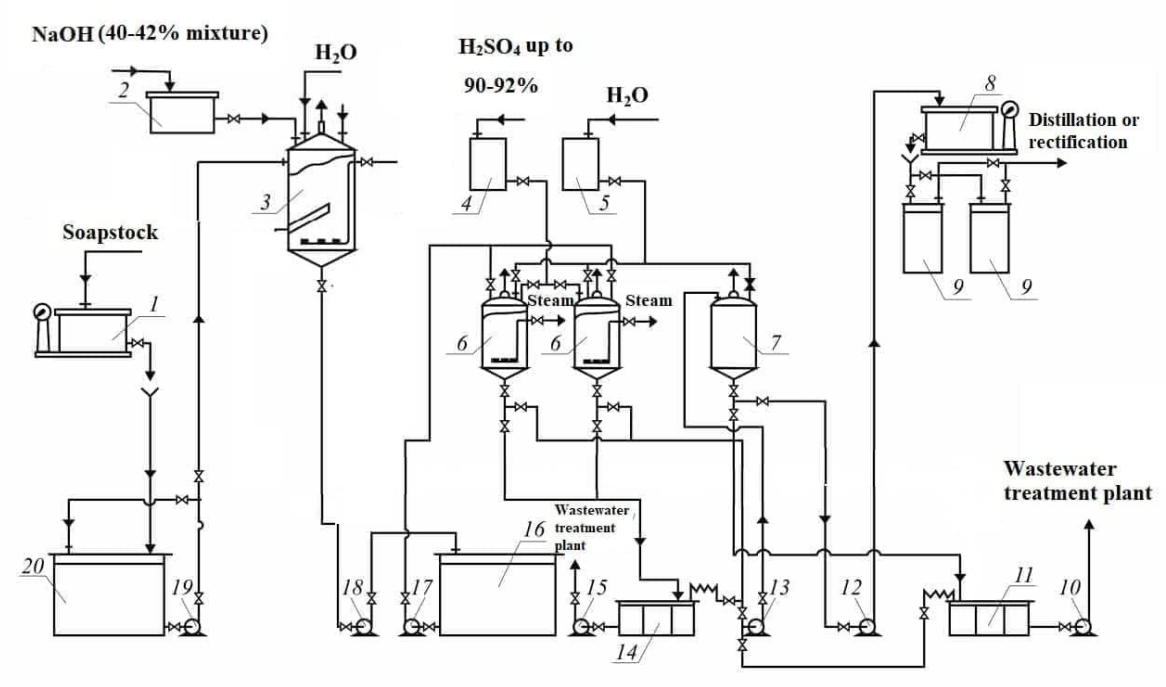

Fig. 1. Basic technological scheme of complex processing of cotton soap stock for crude fatty acids: 1 is capacity for soap stock on the scales; 2 is container for alkali; 3 is soap vessel still; 4 is measuring tank for sulfuric acid; 5 is measurer for water; 6 is reactor-still for decomposition; 7 is washer; 8 is scales; 9 are tanks for crude fatty acids; $10,12,13,15,17,18,19$ are pumps; 11,14 are grease traps; 16 is capacity; 20 is receiving container.

So in a reactor-still (boiler), as a result of the decomposition of saponified soap stock with sulfuric acid, concentrated fatty acid can be obtained up to $95-98 \%$ [2]. The process is carried out using concentrated $\mathrm{H}_{2} \mathrm{SO}_{4}(90-92 \%)$ at a temperature of $80{ }^{\circ} \mathrm{C}$ for an hour. The reactor-boiler 6 is a cylindrical vessel with a conical bottom, lined on the outside with stainless steel and inside with acid-resistant ceramic materials. In this case, sulfuric acid is fed into the reactor in a thin stream to avoid abundant foaming, which leads to the ejection of the mass from the reactor. Unlike Fig. 1, the mixing process can also be carried out simultaneously with bubbling steam $(8 \mathrm{~atm}$.) And the circulation of the mass using a centrifugal pump. Sulfuric acid decomposition of soap stock occurs according to the following equation:

$$
\mathrm{RCOONa}+\mathrm{H}_{2} \mathrm{SO}_{4} \rightarrow \mathrm{RCOOH}+\mathrm{Na}_{2} \mathrm{SO}_{4}
$$

The completion of the decomposition process is usually established by taking a sample 
from the reactor, in which one can observe the formation of two layers - a fat mass on the upper layer and not turbid acidic water in the lower one. After completing the process, the mass is allowed to settle for 1 hour, and the lower acidic layer is poured into a grease trap 14 , from where they are transferred by a pump 15 to a wastewater treatment plant [1].

Whereas the CFA from the reactor-still using the pump 13 is pumped into the washing apparatus 7, into which washing water is supplied from the measuring tank 5 for washing the residual sulfuric acid and sodium sulfate. After sequential settling, the wash water from the apparatus 7 flows by gravity into the grease trap 11, from which they are transferred by the pump 10 to the waste water treatment plant. The washed CFA from the apparatus 7 by the pump 12 is pumped into the container 8 , installed on the scales, and from there, they flow by gravity into the tanks 9 for crude fatty acids. Further, CFA is pumped into distillation stills or a rectification column for distillation of distillation fatty acids or oleic and palmitic fractions, respectively, under a vacuum of 0.6 and $-1 \mathrm{~kg} / \mathrm{cm}^{2}$ or at a residual pressure of $2 \mathrm{~mm} \mathrm{Hg}$ [3]. Typically, in many enterprises, the flushing process is carried out by 100 -fold dilution with pure water [2]. Then the washed acidic wastewater flows by gravity into the grease trap, from where it is pumped to the wastewater treatment plant. It is here that the acidic water from the decomposition reactor and that formed after washing are neutralized with soda ash. However, the generated wastewater is environmentally dirty and causes irreparable damage to the environment. The problem is aggravated because the sulfate content is several times higher than the maximum permissible concentration (MPC). For example, in Russia, in the oil and fat industry enterprises, the concentration of sulfates is $50,000 \mathrm{mg} / 1$ at the MPC norm of $500 \mathrm{mg} / 1$. In Uzbekistan, MPC for sulfates should not exceed $250 \mathrm{mg} / 1$ [4, 5].

So what measures have been taken to efficiently process soap stock or utilize acidic waste water from the CFA production plant?

The work [6] presents the results of a study on the production of detergents from saponified soap stock at the enterprise JSC "Shymkentmay". Good quality detergents received. However, the issue of the utilization of acid waste from soap stock processing has not been resolved here. In work [7], a reagent-free method for processing soap stock is proposed. When splitting, the ratio of water to soapstock fat should be maintained within 1: 0.55-1: 0.6 , the process temperature is up to $94^{\circ} \mathrm{C}$, the duration of the splitting process is 6 hours, the process is carried out in phase III and the introduction of 55-60\%, based on the mass of fat mixtures of water for each phase of cleavage, which ensure the production of fatty acids and glycerin of satisfactory quality. However, at the same time, the depth of fat splitting and the acid number of the obtained fatty acids is 88.87-88.94 \% and acid number $177.7-178.9 \mathrm{mg} \mathrm{KOH} / \mathrm{g}$, respectively. Also, the consumption of sulfuric acid in acidic waters reached $15.38 \%$. The developed approach cannot be avoided from the aggressive effects of acidic water and does not lead to its utilization.

In work [2], acidic water and lye underwent reagent-free treatment using membrane filters under ultrafiltration conditions. They also propose a method of wastewater burnout in spray dryer installations at $700-800^{\circ} \mathrm{C}$. The author managed to prevent the intake of sulfuric acid, sulfate, and sodium chloride and to obtain waste water meeting the MPC standard in terms of quality. In work $[4,5]$, researchers propose to neutralize acidic water under CFA after the first settling with a defect with a coal composition, waste of sugar production. Clear waste water was obtained. However, the issue of utilization of secondary solid waste - sludge after disinfection has not been resolved.

The practice of processing soap stock shows that the process is carried out using sulfuric or other mineral acids in many enterprises and studies. Unfortunately, none of them fully indicates the rational utilization of acidic water before or after its disinfection. However, it is expedient to use the chemical energy of this acidic water with a $\mathrm{pH}$ of 1.5-2 for the decomposition of carbonate phosphorites of a local deposit; for example, Central 
Kyzyl Kum is of practical and scientific interest.

In this regard, employees of the Institute of General and Inorganic Chemistry under Uzbek Academy Sciences, together with employees of JSC "Urganch yog'-moy" and the Department of Food Technology of Urgen University, conducted research on the neutralization of acidic water obtained from the first CFA settling process with highcarbonate phosphorite of Central Kyzylkum. The process of neutralizing acidic water was carried out using a drainless technology, i.e., after neutralization, the reaction mixture did not separate into liquid and solid phases.

\section{Materials and Methods}

The acidic water of JSC "Urganch yog'-moy", obtained from the first process of settling CFA due to decomposition of saponified soap stock, was used as the object of the study. Physical parameters and chemical composition of acidic water were determined according to the method [8]. $\mathrm{Na}^{+}$and $\mathrm{K}^{+}$were determined by flame photometry, and the spectrometric method was used to determine $\mathrm{NH}_{4}^{+}, \mathrm{NO}_{2}^{-}, \mathrm{Fe}^{2+}, \mathrm{Fe}^{3+}$ ions by $[9,10] . \mathrm{Ca}^{2+}$ and $\mathrm{Mg}^{2+}$ were determined by complexometric method, and $\mathrm{CO}_{3}{ }^{2-}, \mathrm{HCO}_{3}{ }^{-}$by titration with Trilon $\mathrm{B} . \mathrm{NO}_{3}{ }^{-}$ by potentiometric method, $\mathrm{SO}_{4}{ }^{2-}$ and dry residue were determined by gravimetric method [11]. The results of analyzes of acidic water are presented in Tables 1 and 2. Whereas the neutralizing agent of this acidic water was used phosphorite flour from the Central Kyzylkum deposit, crushed to a fineness of grains of $0.25 \mathrm{~mm}$ composition $\mathrm{P}_{2} \mathrm{O}_{5}-17.54$; $\mathrm{CaO}$ 47.75; $\mathrm{MgO} 1.79 ; \mathrm{CO}_{2}-16.5 ; \mathrm{Fe}_{2} \mathrm{O}_{3}-0.73 ; \mathrm{Al}_{2} \mathrm{O}_{3}$ 0.95; $\mathrm{SO}_{3} 4.06 ; \mathrm{F}$ - 1.7; $\mathrm{SiO}_{2}$ 1.24; insoluble residue - 4.03; $\mathrm{CaO}: \mathrm{P}_{2} \mathrm{O}_{5}-2.72$.

The method of conducting experiments on neutralization of acidic water was carried out at a mass ratio of acid waster water and phosphorite powdered as $\mathrm{AWW}: \mathrm{PH}=100$ : 10 , 100: 15, 100: 20, 100: 25, 100:30, 100: 35 and 100: 40 at a temperature of $60^{\circ} \mathrm{C}$ and a time duration of $30 \mathrm{~min}$. Laboratory experiments were carried out in a $500 \mathrm{ml}$ temperaturecontrolled glass reactor equipped with a helical stirrer at a speed of 250-300 rpm. The process temperature was controlled with a thermostat. When the set temperature was reached, the calculated amount of the phosphorite sample was introduced into the reactor. The reaction mixture was stirred at a given process temperature and time of interaction of the components. After completing the process, the contents in the reactor were poured into porcelain bowls and dried at a temperature of $80{ }^{\circ} \mathrm{C}$, while carrying out the pelletizing process by the pelletizing method.

Table 1. Indicators of waste water from the first settling process of the deoxidation plant for saponified soap stock

\begin{tabular}{|c|c|c|c|c|c|c|c|c|c|}
\hline \multirow{2}{*}{$\begin{array}{l}4 \\
0 \\
0\end{array}$} & \multirow{2}{*}{ 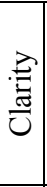 } & \multirow{2}{*}{ 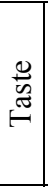 } & \multirow{2}{*}{$\frac{\dot{0}}{0}$} & \multirow{2}{*}{$\begin{array}{l}\vec{z} \\
\overline{0} \\
0\end{array}$} & \multicolumn{2}{|c|}{ Hardness, meq/l } & \multicolumn{2}{|c|}{$\begin{array}{l}\text { Dry residue } \\
\mathrm{mg} / 1\end{array}$} & $\begin{array}{c}\text { Suspended } \\
\text { substances, } \\
\mathrm{mg} / 1\end{array}$ \\
\hline & & & & & $\begin{array}{c}\text { Carbona } \\
\text { te }\end{array}$ & $\begin{array}{c}\text { Non- } \\
\text { carbonate }\end{array}$ & $\begin{array}{l}\text { Experime } \\
\text { ntal }\end{array}$ & $\begin{array}{c}\text { Estimate } \\
\mathrm{d}\end{array}$ & \\
\hline 2.0 & 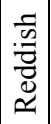 & $\begin{array}{l}\circ \\
\stackrel{2}{2} \\
\stackrel{2}{2}\end{array}$ & 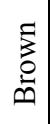 & 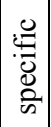 & 56.50 & 108.50 & 140.51 & 134.24 & 6185 \\
\hline
\end{tabular}


Table 2. Chemical composition of waste water from the first sedimentation process of the saponified soap stock deoxidation workshop

\begin{tabular}{|c|c|c|c|c|c|c|c|}
\hline Cations & $\mathrm{mg} / \mathrm{l}$ & $\mathrm{meq} / \mathrm{l}$ & $\%-\mathrm{eq} / \mathrm{l}$ & Anions & $\mathrm{mg} / \mathrm{l}$ & $\mathrm{meq} / \mathrm{l}$ & $\begin{array}{c}\% \text {-eq } \\
/ 1\end{array}$ \\
\hline $\mathrm{H}+$ & 100 & 100 & 87 & $\mathrm{Cl}-$ & 38116 & 1075 & 50 \\
\hline $\mathrm{Na}+$ & 43158 & 1876.46 & - & $\mathrm{SO} 42-$ & 48145 & 1003.03 & 47 \\
\hline $\mathrm{K}+$ & - & - & - & NO2- & 20.01 & - & - \\
\hline $\mathrm{NH} 4+$ & 100 & 5,54 & - & $\mathrm{NO} 3-$ & 840 & 13.55 & - \\
\hline $\mathrm{Ca} 2+$ & 300 & 15 & 1 & $\mathrm{CO} 3-$ & - & - & - \\
\hline $\mathrm{Mg} 2+$ & 1824 & 150 & 7 & HCO3- & 3446 & 58.50 & 3 \\
\hline $\mathrm{Fe} 3+$ & 0.3 & 0.01 & - & Total & & 2148.08 & 100 \\
\hline $\mathrm{Fe} 2+$ & 30 & 1.07 & - & & & & \\
\hline Total & & 2148.08 & 100 & & & & \\
\hline
\end{tabular}

Chemical analysis of raw materials and products for the content of various components was carried out according to the methods [12].

The determination of P2O5 was carried out in a differential way on a KFK-3 device (wavelength $\lambda=440 \mathrm{~nm}$ ) in the form of a phosphoric-vanadium-molybdenum complex. $\mathrm{SO}_{3}$ - by weight - precipitation in the form of $\mathrm{BaSO}_{4}$. The content of $\mathrm{CaO}$ and $\mathrm{MgO}$ was determined by the volumetric complexometric method: titration with $0.05 \mathrm{~N}$ solution of Trilon $\mathrm{B}$ in the presence of fluorexon and chromium dark blue indicators, respectively. Analysis for $\mathrm{Al}_{2} \mathrm{O}_{3}$ and $\mathrm{Fe}_{2} \mathrm{O}_{3}$ was also performed by the complexometric method by titration with $0.05 \mathrm{~N}$ solution of Trilon $\mathrm{B}$ in the presence of xylene-orange indicator and sulfosalicylic acid, respectively. The $\mathrm{CO}_{2}$ content was determined by the volumetric method by decomposition of carbonates with dilute hydrochloric acid. Determination of $\mathrm{F}$ was carried out by potentiometric method using a fluorine selective electrode. $\mathrm{SiO}_{2}$ was determined by the gravimetric method with the precipitation of silicic acid using gelatin and the insoluble residue in aqua regia.

The assimilable (ass.) form of $\mathrm{P}_{2} \mathrm{O}_{5}$ was determined by its solubility in both $2 \%$ citric acid and $0.2 \mathrm{M}$ Trilon $\mathrm{B}$. The amount of carbon dioxide in the phosphate raw material and products was determined by the volumetric method.

\section{Results and Discussions}

The chemical analysis results are shown in Table 3.

Table 3. Composites of acidic water neutralization products from CFA production with highcarbonate phosphorite of Central Kyzylkum

\begin{tabular}{|c|c|c|c|c|c|c|c|c|}
\hline 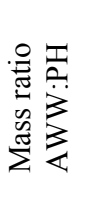 & 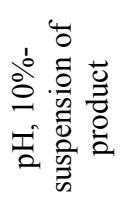 & $\begin{array}{l}\bar{\pi} \\
\stackrel{\pi}{0} \\
\stackrel{0}{0} \\
0 \\
0\end{array}$ & 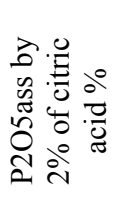 & 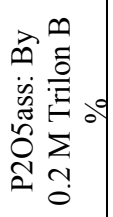 & 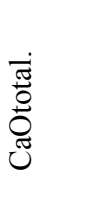 & SO3 & 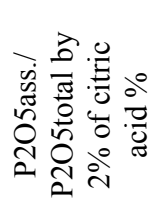 & 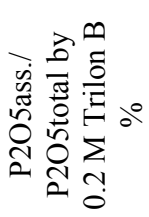 \\
\hline 1 & 2 & 3 & 4 & 5 & 6 & 7 & 8 & 9 \\
\hline 100:10 & 4.0 & 9.34 & 4.71 & 3.73 & 26.44 & 22.13 & 50.43 & 39.93 \\
\hline $100: 15$ & 4.9 & 11.75 & 5.44 & 4.12 & 28.52 & 20.47 & 46.30 & 35.06 \\
\hline $100: 20$ & 5.5 & 13.36 & 5.07 & 4.03 & 32.53 & 16.54 & 37.95 & 30.16 \\
\hline $100: 25$ & 5.8 & 13.67 & 5.05 & 4.08 & 33.68 & 15.06 & 36.94 & 29.85 \\
\hline $100: 30$ & 6.2 & 14.29 & 4.88 & 3.86 & 34.13 & 14.74 & 34.15 & 27.01 \\
\hline $100: 35$ & 6.6 & 14.97 & 4.75 & 3.92 & 35.59 & 12.36 & 31.73 & 26.18 \\
\hline $100: 40$ & 7.1 & 15.09 & 4.57 & 3.86 & 36.96 & 11.49 & 30.28 & 25.58 \\
\hline
\end{tabular}


As can be seen from Table 3, an increase in the mass fraction of phosphate rock from 100: 10 to 100: 40 leads to an increase in the content of the total form of $\mathrm{P}_{2} \mathrm{O}_{5}$ from 9.34 to $15.09 \%$. Simultaneously, the $\mathrm{CaO}$ content ranges from 26.44 to $36.96 \%$ since the products contain an assimilable form of $\mathrm{P}_{2} \mathrm{O}_{5}$ for citric acid and Trilon $\mathrm{B}$ from 4.71 to 5.44 and from 3.73 to $4.08 \%$, respectively. The relative contents of assimilable forms of $\mathrm{P}_{2} \mathrm{O}_{5}$ for citric acid and Trilon $\mathrm{B}$ increase with an increase in the mass ratio of AWW: $\mathrm{PH}$ within 30.28 50.43 and $25.58-39.93 \%$, respectively. The decrease in the assimilable forms of $\mathrm{P}_{2} \mathrm{O}_{5}$ is explained by an increase in the neutralizing addition of phosphorite flour simultaneously with an increase in the $\mathrm{pH}$ of a $10 \%$ suspension of products in the range 4.0-7.1. Additionally, all SO3 cumulated in the product ranged from 11.49-22.13\%. The undecomposed carbonate $\left(\mathrm{CO}_{2}\right)$ in the products also increases from 4.02 to $10.23 \%$ versus the initial $16.5 \%$. These products can be called activated forms of phosphorus fertilizers, which can be successfully used as the main fertilizer under the autumn plow. After all, it is known that agrochemists and soil scientists recommend the use of single phosphorus fertilizers as simple and double superphosphate under the autumn plow, where their effectiveness is greatest. It should be noted that organic substances in acidic water also contribute to an increase in the assimilable $\mathrm{P}_{2} \mathrm{O}_{5}$ in food. Also, the Central Kyzyl Kum phosphorites are quite acceptable for obtaining both organomineral phosphorus-containing ones by acidifying poultry manure and off-balance ore with nitric acid and mineral phosphorus fertilizers with high digestible forms of $\mathrm{P}_{2} \mathrm{O}_{5}$ [13].

The fertilizers obtained by us have a static strength of at least $2.0 \mathrm{MPa}$. This can be explained by the binding capacity of sodium sulfate in the product. However, this study requires further development to assess the agrochemical effectiveness of products and other indicators.

\section{Conclusion}

Thus, for the first time, it is proposed to use the large-scale industrial waste of the oil and fat industry-acidic water with high-carbonate phosphorite of the Central Kyzyl Kum, using a drainless technology. As a result of the rational use of the chemical energy of acidic water from the soap stock processing shop with carbonate phosphorite, a valuable product can be obtained as a one-sided phosphorus fertilizer in activated form. The products contain in their composition the relative forms of $\mathrm{P}_{2} \mathrm{O}_{5}$ for citric acid and Trilon $\mathrm{B}$ in the range of $30.28-50.43$ and $25.58-39.93 \%$, respectively. These types of fertilizers are quite acceptable when they are recommended for use under the fall for grain and oilseeds.

\section{References}

1. Sergeeva A.G. Guidelines for the technology of obtaining and processing vegetable oils and fats, Leningrad, p. 527, (1975)

2. Machigin V.S. Purification of greasy wastewater by ultrafiltration and fire neutralization. Dissertation for the degree of Doctor of Technical Sciences. St. Petersburg, (2006)

3. TR 1602-28-03-09. Production technological regulations for the processing of cotton soap stock, obtaining fatty acids, rectification of fatty acids to obtain palmitin and olein grade "A". Tashkent, 91 p. (2009)

4. Usmanov R., Salikhanova D., Kuldasheva Sh., Eshmetov I., Abdurakhimov S. Cleaning of waste water for fatty production by waste of sugar production-defecate. Austrian Journal of Technical and Natural Sciences Scientific journal № 9-10 pp. 8286, Vienna, (2018) 
5. Usmanov R., Eshmetov I., Salikhanova D., Agzamova F., Eshmetov R., Sharipov A. Physical-Chemical Properties of Thermoactivated Defecate for Purification of Acid Waste Waters, International Journal of Innovative Technology and Exploring Engineering (IJITEE ) ISSN: 2278-3075, 9 (2), pp.1184-1186, (2019).

6. Olzhataev B.A., Aydar U.T., Utelbaev B.T., Turekulov E.T. Technology of obtaining liquid detergents from soap stock of JSC "Shymkentmay". Chemical industry today, pp. 35-37, (2004)

7. Ravshanov D.A., Kadirov Yu.K. On the issue of processing technology for cotton soap stock. Collection of scientific articles of the 5th All-Russian scientific and technical conference with international participation. Progressive technologies and processes, pp. 206-211. Kursk September (2018).

8. O'zDSt 950: 2011. Drinking water Hygiene requirements and quality control. p. 13.

9. Popova L.F. Analytical chemistry with the basics of physical and chemical methods of analysis, Workshop, (2014)

10. Slepushkin BM, Stifatov Yu.V., Rublinetskaya E.Yu. Analytical chemistry. Chemical methods of analysis, p. 232. (2011).

11. Vinnik M.M., Erbanova L.N., Zaitsev P.M. Methods for the analysis of phosphate raw materials,Phosphorus and complex fertilizers, feed phosphates. Moscow, Chemistry, (1975).

12. Temirov U.Sh., Namazov Sh.S., Usanbayev N.Kh.. Intensive technology for processing bird litter in organomineral fertilizers. Izvestiya vysshikh uchebnykh zavedenii khimiya khimicheskaya tekhnologiya, 63(12), pp. 85-94, (2020), https://doi.org/10.6060/ivkkt.20206312.6210. 